Поспєлов С. В., кандидат сільськогосподарських наук

Полтавська державна аграрна академія

\title{
ОСОБЛИВОСТІ РОЗВИТКУ СУЦВІТЬ І ЦВІТІННЯ EXIHАЦЕÏ ПУРПУРОВОÏ (ECHINACEA PURPUREA (L.) MOENCH) ТА ЕХІНАЦЕЇ БЛІДОÏ (ЕCHINACEA PALLIDA (NUTT.) NUTT.) В ЛІСОСТЕПУ УКРАЇНИ
}

\section{Резензент - доктор сільськогосподарських наук, професор В. М. Тищенко}

\begin{abstract}
В умовах Лісостепу Украӥни досліджено закономірності цвітіння ехінацеї пурпурової (Echinacea purpurea (L.) Moench), сорту Зірка Миколи Вавилова й ехінацеї блідої (Echinacea pallida (Nutt.) Nutt.) сорту Красуня прерій. Вперше за багаторічними даними у виробничих умовах встановлено, щуо ехіначея пурпурова починає утворення суцвіть із травня, масове квітування - з липня. Одна рослина за сезон утворює 48,2 шт. кошиків масою 184,25 2. Період квітування кошика першого порядку триває в середньому 34 доби, інших порядків - 33-43

доби. Загальний період квітування рослини -

близько 65 діб. Ехінацея бліда починає утворення суивіть у травні, масове квітування у червні. Рослина за сезон утворює в середньому 10,4 шт. суцвіть масою 30,1 г. Кочик першого порядку квітує до 15 діб, іниих порядків - 19-29 діб. Загальний період иввітіння рослини триває 34-37 діб. Дослідження дають змогу враховувати біологічні особливості в разі конструювання лікарських, кормових i медоносних агроценозів ехінацеї, планування збору надземної маси на лікарську сировину, регулящії продуктивності й тривалості ивітіння.
\end{abstract}

Ключові слова: ехінацея пурпурова, Echinacea pиrригеа (L.) Moench, Зірка Миколи Вавилова, ехіначея бліда, Echinacea pallida (Nutt.) Nutt., Красуня прерій, онтогенез, суцьвіття, кошики, иввітіння.

Постановка проблеми. Рід Ехінацея (Echinacea Moench.) активно вивчається у світі завдяки комплексному використанню у медицині, ветеринарії, тваринництві, кормовиробництві, харчовій і косметичній промисловості [7, 11]. Популярність використання ехінацеї тримається на високому рівні вже багато років, що пояснюється унікальним фітохімічним складом ії компонентів [7]. В Україні інтродуковані й вирощується два види: ехінацея пурпурова (Echinacea purpurea (L.) Moench) та ехінацея бліда (Echinacea pallida (Nutt.) Nutt.). Сировиною для переробки слугують надземна частина і кореневища 3 коренями, які збирають, як правило, на другий-третій рік вегетації. Для вибору оптима- льних строків збирання надземної маси важливо знати основні закономірності розвитку суцвіть, тривалість цвітіння, тому що суцвіття досить суттєво впливають на кількісні показники урожаю, а ще більше - на якісні, поскільки містять значну кількість хімічних сполук, від яких залежить якість сировини. Особливості проходження онтогенезу відіграють важливу роль у пору медоносного використання плантацій ехінацеї, прогнозування насіннєвої продуктивності тощо.

Аналіз основних досліджень і публікацій, у яких започатковано розв'язання проблеми. Перехід до генеративного періоду онтогенезу ехінацеї супроводжуються утворенням і розвитком пагонів, на яких утворюються суцвіття - кошики. Біологія цвітіння й опилення роду Echinacea Moench. найбільш глибоко вивчено дослідником університету Саскачеван (Канада) Tyler J. Wist [14]. Серед вітчизняних дослідників особливості цвітіння, запилення, нектаропродуктивності в різні роки вивчали Г. К. Смик, В. О. Меньшова $[5,8]$, Т. Д. Соломаха [9], О. А. Порада [6], О. І. Черкасова, Л. М. Солошенко [10], Т. О. Журавель [2].

Кошики ехінацеї пурпурової утворюються на генеративному пагоні: першим розвиваються суцвіття першого порядку, згодом - інших порядків на бічних пагонах. Спочатку квітколоже плескате, з розвитком кошика змінюе свою форму до випуклої, а під час цвітіння - до конічної [2]. Крайові квітки у кошику - від білого до густо-пурпурового забарвлення, стерильні (неплідні), горизонтально-відлеглі або відігнуті донизу, довжиною 3,5-7,5 см, шириною 3-7 мм, на суцвітті $12-30[1,5,8]$. Кут відгину крайових квіток залежить від віку суцвіття, а може бути сортовою ознакою. Поскільки ехінацея ентомофільна рослина, то крайові квітки виконують функцію приваблення й принадження комах до неї. Період їх цвітіння - 35-45 діб [2], однак вони не втрачають форми і забарвлення близько 40-55 діб [11].

Серединні квітки - трубчасті, двостатеві, пло- 
доносні. Мають короткий 5-зубчастий відгин. Забарвлені вони, зазвичай, у темно-пурпуровий колір. Конічне квітколоже густо вкрите перетинчастими, лінійно-ланцетними загостреними лусочками (приквітками) також пурпурового кольору, котрі виступають поверх трубчастих квіток і роблять суцвіття схожим на їжака (звідси латинська назва родини). Суцвіття утворює від 10 до 18 кіл трубчастих квіток загальною кількістю від 30 до $350[2,12]$, кожна з яких квітує 2-3 доби $[2,9]$. Окрема квітка квітує 2-4 доби $[2,9$, 12], успішність запилення залежить від погодних умов і комах. Цвітіння акропетальне. Тривалість цвітіння одного суцвіття від 12-20 [12] до 35-45 діб [4], усієї рослини (за різними оцінками) від 25-35 до 38-58 діб [10, 12].

Аналіз літературних джерел свідчить, що більшість наведених даних досить сильно варіюють, що, ймовірно, пов'язано з географічним розташуванням місця досліджень, екологічними умовами та сортовими особливостями. Крім того, наведені вище характеристики стосуються виключно ехінацеї пурпурової й ехінацеї вузьколистої; що стосується ехінацеї блідої, то вони мають епізодичний характер $[12,13]$.

Мета досліджень та методика їхнього проведення. Метою наших досліджень було вивчення закономірності розвитку суцвіть і тривалості цвітіння ехінацеї пурпурової сорту Зірка Миколи Вавилова й ехінацеї блідої сорту Красуня прерій, культивовані в Полтавській області.

Спостереження за утворенням і розвитком суцвіть проводили в умовах виробничих плантацій СК «Радянський» Кобеляцького району Полтавської області в 2001-2005 роках. Для цього 3 травня по вересень рендомізовано відбирали по 15 рослин, на яких рахували кількість пагонів; із кожного зрізали суцвіття, обміряли й зважували в лабораторних умовах. У ході вимірювання діаметра крайові квітки не враховувались.

Динаміку розвитку суцвіть і тривалість цвітіння вивчали в 2006-2007 роках в умовах ботанічного саду Полтавського Національного педагогічного університету ім. В. Г. Короленка. На дослідних ділянках ехінацеї другого року вегетації вимічали по десять модельних рослин, на яких періодично вимірювали діаметр суцвіть та довжину відгину крайової квітки, оцінювали ступінь цвітіння суцвіття за колами трубчатих квіток.

Отримані дані обробляли методом статистичного і регресійного аналізів за допомогою пакета EXEL.

Результати дослідження. В умовах виробни- чих посівів нами вивчався сезонний ритм розвитку суцвіть ехінацеї пурпурової на рівні одного генеративного пагона й однієї рослини. Проведені спостереження свідчать, що їх утворення розпочинається у травні й продовжується до липня (табл. 1). На одну рослину їх розвивається до 48,3 шт. загальною масою 184,25 г. Середня кількість суцвіть на один пагін становить 5,1 шт. масою 19,6 г. У фазу цвітіння середній діаметр суцвіття сягає трьох сантиметрів.

Перші суцвіття утворюються в травні на головному пагоні, з часом вони поступово розвиваються на пагонах другого, третього та інших порядків, яких на стеблі може утворюватися до 1012. За рахунок цього на одній рослині спостерігаються як нерозквітлі суцвіття, так і кошики, які вже закінчили квітувати. В середньому на рослині у травні налічується нерозквітлих суцвіть 0,25 шт., у червні - 9,6 шт., у липні 26,2 шт. масою 0,21 г, 11,5 г та 46,6 г відповідно. $\mathrm{У}$ кінці червня суцвіття першого порядку починають квітувати. Наші спостереження свідчать, що в перший місяць літа їх квітує в середньому 0,9 шт. масою 3,43 г. У липні їх кількість стрімко зростає до 20,2 шт., а у серпні - до 46,7 штук. Середня маса суцвіть однієї рослини становить відповідно по місяцях 73,1 та 169,2 г. Середня маса одного суцвіття досить стала і коливається у межах 3,62-3,82 г.

Питання розвитку суцвіть і тривалості їх цвітіння в літературі висвітлені недостатньо, а під час і суперечливо $[1,2,13]$. За даними різних дослідників, ехінацея пурпурова квітує від одного місяця до двох і більше. Причин цього, на нашу думку, декілька. По-перше, зазвичай вважають, що квітування починається, коли на суцвітті забарвлюються крайові квітки. В той же час Tyler J. Wist [14] за початок цвітіння бере розпускання трубчастих квіток, коли починається продуктивне запилення рослин. По-друге, тривалість цвітіння суцвіть на одному пагоні подовжується за рахунок поступового базипетального квітування рослини. I, насамкінець, в агроценозі рослини розвиваються неодночасно, із певними відхиленнями у часі, що створює ілюзію довготривалого квітування. Індивідуальні особливості онтогенезу можуть коректуватися агрометеорологічними умовами року. Наприклад, у 2003 році в базовому господарстві у липні спостерігалася грунтова й повітряна посухи, що призвело до підсихання листків, суцвіть, припинення запилення.

Все це примусило нас більш ретельно вивчити динаміку цвітіння ехінацеї пурпурової. На рису- 
нку 1 зображена динаміка збільшення діаметра суцвіть 1-9-го порядків. Наші дослідження свідчать, що суцвіття першого порядку суттєво відрізняється за своїми параметрами від інших. Його діаметр збільшувався на протязі 60 діб, а середня швидкість росту складала 0,64 мм за добу. За цей період діаметр суцвіття зріс від 2,72 мм до 41,4 мм. Ростові процеси з високою точністю описуються поліномами третього і другого порядків: $\mathrm{Y}=-0,0001 \mathrm{X}^{3}+0,0127 \mathrm{X}^{2}+0,3293 \mathrm{X}+0,1436$ $\left(\mathrm{R}^{2}=0,9946\right) ; \mathrm{Y}=-0,0039 \mathrm{X}^{2}+0,945 \mathrm{X}-5,7867$ $\left(\mathrm{R}^{2}=0,9893\right)$. Перше суцвіття завжди було більше за розміром від суцвіть інших порядків не менше ніж на 6,6 мм.

\section{1. Характеристика розвитку суцвіть ехінацеї пурпурової (2001-2003 рр.)}

\begin{tabular}{|c|c|c|c|c|c|}
\hline \multirow{2}{*}{ Показники } & \multicolumn{5}{|c|}{ Відбори: } \\
\cline { 2 - 6 } & травень & червень & липень & серпень & вересень \\
\hline \multicolumn{7}{|c|}{ Нерозквітлі суцвіття } \\
\hline Кількість на рослину, шт. & 0,25 & 9,60 & 26,2 & - & - \\
\hline Кількість на один пагін, шт. & 0,034 & 1,05 & 2,91 & - & - \\
\hline Маса суцвіть однієї рослини, г & 0,21 & 11,49 & 46,58 & - & - \\
\hline Маса суцвіть на один пагін, г & 0,03 & 1,26 & 5,18 & - & - \\
\hline Маса одного суцвіття, г & 0,84 & 1,19 & 1,77 & - & - \\
\hline Діаметр суцвіття, см & 1,22 & 2,10 & 2,40 & - & - \\
\hline \multicolumn{7}{|c|}{ Розквітлі суцвіття } \\
\hline Кількість на рослину, шт. & - & 0,90 & 20,20 & 46,67 & 48,23 \\
\hline Кількість на один пагін, шт. & - & 0,098 & 2,24 & 5,073 & 5,13 \\
\hline Маса суцвіть однієї рослини, г & - & 3,43 & 73,12 & 169,20 & 184,25 \\
\hline Маса суцвіть на один пагін, г & - & 0,38 & 8,12 & 18,40 & 19,60 \\
\hline Маса одного суцвіття, г & - & 3,81 & 3,62 & 3,63 & 3,82 \\
\hline Діаметр суцвіття, см & - & 3,18 & 3,52 & 2,52 & 2,41 \\
\hline \multicolumn{7}{|c|}{ Разом суцвіть } & & \\
\hline Кількість на рослину, шт. & 0,25 & 10,50 & 46,20 & 46,67 & 48,23 \\
\hline Кількість на один пагін, шт. & 0,034 & 1,15 & 5,13 & 5,07 & 5,13 \\
\hline Маса суцвіть однієї рослини, г & 0,21 & 14,92 & 119,70 & 169,20 & 184,25 \\
\hline Маса суцвіть на один пагін, г & 0,03 & 1,64 & 13,30 & 18,39 & 19,60 \\
\hline Маса одного суцвіття, г & 0,84 & 1,42 & 2,59 & 3,63 & 3,82 \\
\hline Діаметр одного суцвіття, см & 1,22 & 2,64 & 2,96 & 2,52 & 2,41 \\
\hline
\end{tabular}

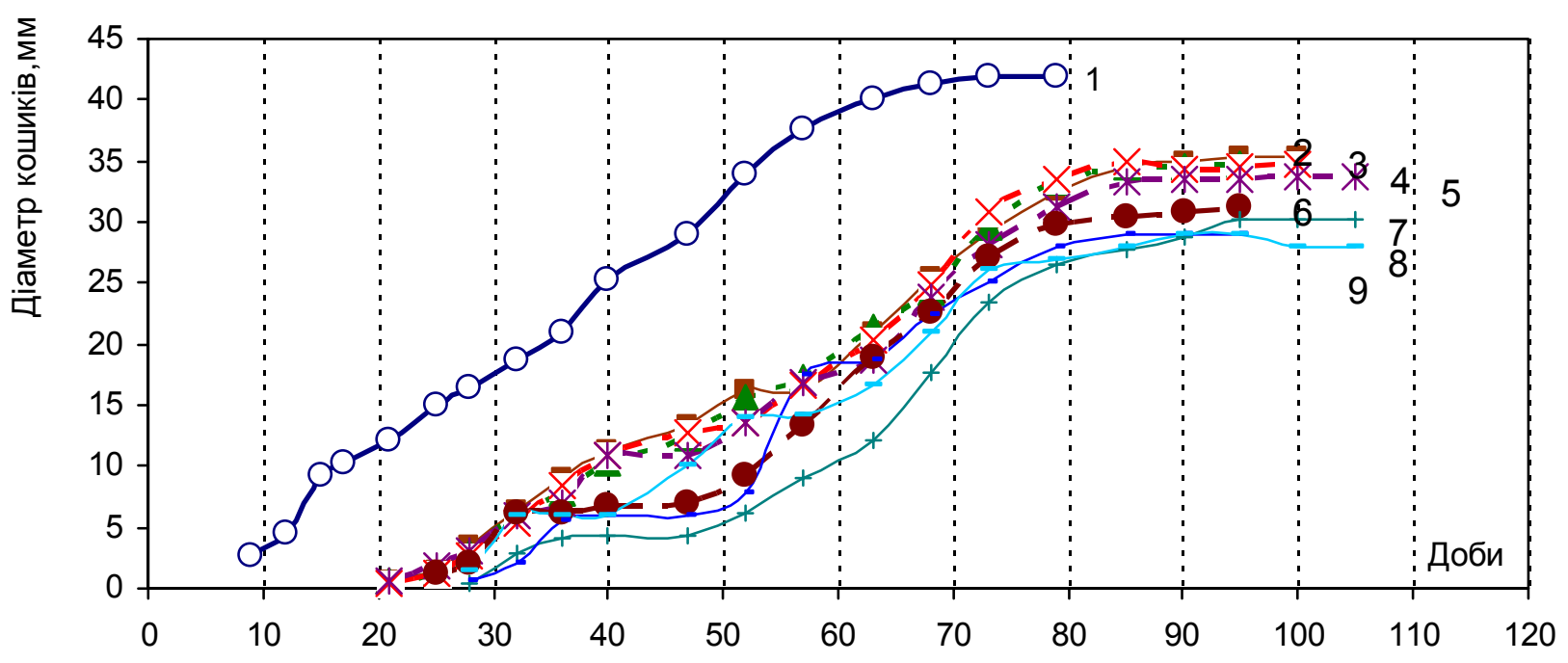

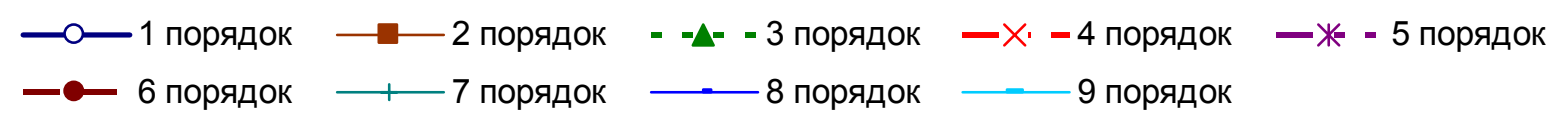

Рис. 1. Динаміка зростання діаметра суцвіть ехінацеї пурпурової 


\section{СІЛЬСЬКЕ ГОСПОДАРСТВО. РОСЛИННИЦТВО}

Суцвіття другого-п'ятого порядків починали утворюватися через 9-12 діб після першого, їх розвиток не був таким динамічним і стрімким. На рисунку 1 видно, що спостерігаються певні відрізки часу, коли ріст гальмувався, а потім продовжувався. Це було притаманніше суцвіттям більш низьких порядків (шостий-дев'ятий). Це, з нашого погляду, пов'язано з агрокліматичними умовами, коли могло не вистачати грунтової вологи, а також із гормональними факторами рослини, коли спостерігається пріоритет росту кошиків більш високих порядків. Доказом цього $\epsilon$ той факт, що в наших дослідах деякі суцвіття шостого-десятого порядків утворилися, проте пагони припинили ріст, а суцвіття не набули подальшого розвитку.

Максимальний діаметр суцвіть 2-4-го порядків був майже однаковим (34,8-35,3 мм), а суцвіття інших порядків мали менші показники 28,0-33,6 мм. Нами встановлено, що зупинка росту суцвіть співпадає із закінченням квітування кошиків, що, безумовно, свідчить про гормональну перебудову рослини, пов'язану із процесом плодоутворення.

На рисунку 2 наводяться дані розвитку суцвіть ехінацеї пурпурової різних порядків. Вони дають змогу дійти висновку, що збільшення діаметра суцвіття і довжини крайових квіток тісно взаємопов'язані. Від початку утворення суцвіття до початку висування крайових квіток проходить 20-28 діб. Найбільш повільно цей процес відбувається у суцвіть першого порядку. На рисунку видно, що крайові квітки ростуть досить швидко - до 4 мм/добу, їх довжина стає більшою від діаметра суцвіття, але їх ріст припиняється раніше, ніж повний розвиток кошика. За рахунок цього наприкінці цвітіння довжина пелюсток і діаметр суцвіття стають майже однаковими. Ріст суцвіть

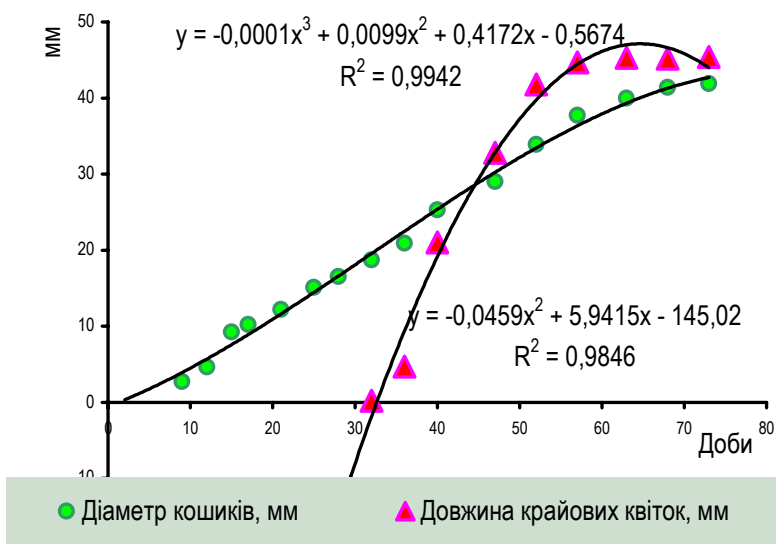

Перший порядок і крайових квіток із високою точністю описується поліноміальними рівняннями, що наведені на рисунку 2.

Важливою характеристикою ехінацеї пурпурової є тривалість цвітіння. Це визначає як термін використання надземної маси для потреб фармацевтичної промисловості, так і їі медоносні властивості.

Наші дослідження свідчать, що через чотиришість діб після висування пелюсток крайових квіток суцвіття першого порядку починає квітувати (рис. 3), що триває в середньому 34 доби. Через 17 діб після першого починається цвітіння суцвіть 23-го порядків, через 5-6 діб - інших порядків. Бічні суцвіття квітують дещо більше - до 43-х діб. Із наведеного рисунка видно, що загальний період квітування становить близько 65 діб.

Вивчені закономірності відкривають можливості регулювання процесу цвітіння шляхом застосування регуляторів росту, агротехнічних заходів, виведення нових сортів тощо. Водночас слід зауважити, що вказані аспекти маловивчені й практично не застосовуються у виробництві.

Поряд із ехінацеєю пурпуровою ми вивчали біологію цвітіння ехінацеї блідої - перспективного інтродуцента, який вивчається нами протягом 20 років. Дослідження дали нам змогу встановити основні закономірності утворення суцвіть (табл. 2). Суцвіття утворюються в травні, а вже в червні починають квітувати, тобто період їх розвитку (порівняно з ехінацеєю пурпуровою) більш скорочений, і всі ростові процеси проходять доволі інтенсивно. У період квітування в середньому на одну рослину їх розвивається 8,8 шт. загальною масою 53,14 г. На одному пагоні утворюється 3,3 кошика масою 17,14 г. У цей період маса одного суцвіття $(6,05$ г) і його діаметр $(3,16)$ сягають свого максимуму.

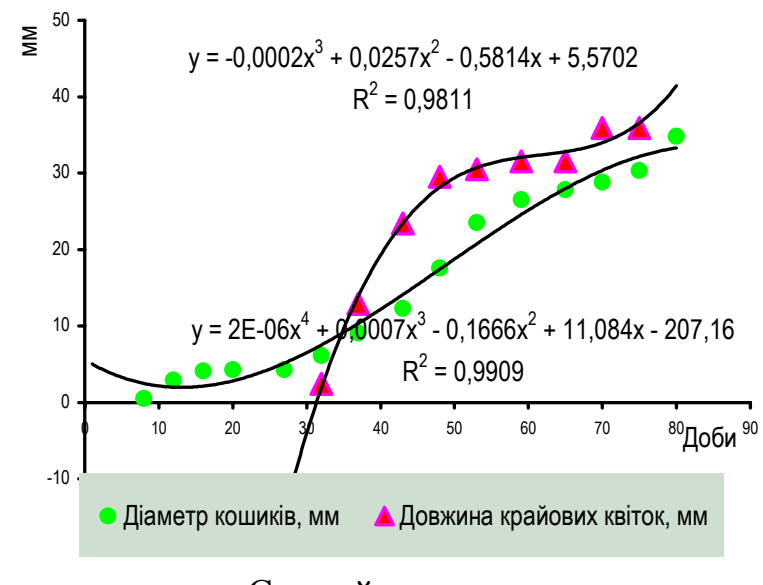

Сьомий порядок

Рис. 2. Динаміка розвитку суцвіть ехінацеї пурпурової 


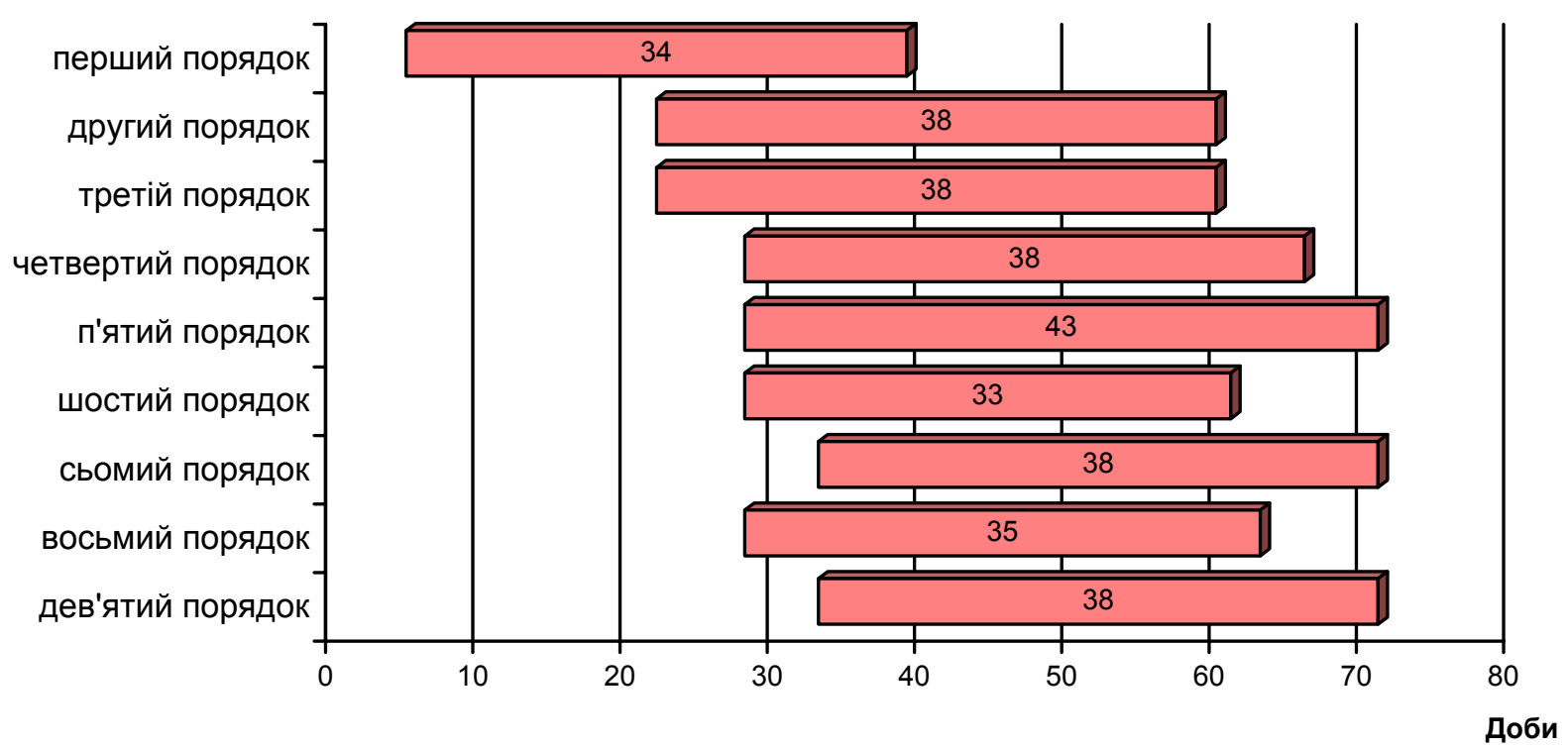

Рис. 3. Тривалість цвітіння суцвіть ехінацеї пурпурової (від початку висування крайових квіток) (2006-2007 рр.)

2. Характеристика розвитку суцвіть ехінацеї блідої (2003-2005 рр.)

\begin{tabular}{|c|c|c|c|c|c|}
\hline \multirow{2}{*}{ Показники } & \multicolumn{5}{|c|}{ Відбори: } \\
\hline & травень & червень & липень & серпень & вересень \\
\hline \multicolumn{6}{|c|}{ Суцвіття нерозквітлі } \\
\hline Кількість на рослину, шт. & 7,4 & 4,0 & - & - & - \\
\hline Кількість на один пагін, шт. & 1,9 & 1,5 & - & - & - \\
\hline Маса суцвіть однієї рослини, г & 5,33 & 10,74 & - & - & - \\
\hline Маса суцвіть на один пагін, г & 1,41 & 3,98 & - & - & - \\
\hline Маса одного суцвіття, г & 0,73 & 2,68 & - & - & - \\
\hline Діаметр суцвіття, см & 0,98 & 0,85 & - & - & - \\
\hline \multicolumn{6}{|c|}{ Суцьвіття розквітлі } \\
\hline Кількість на рослину, шт. & - & 4,1 & 8,8 & 9,2 & 10,4 \\
\hline Кількість на один пагін, шт. & - & 1,5 & 2,8 & 3,1 & 4,7 \\
\hline Маса суцвіть однієї рослини, г & - & 31,61 & 53,14 & 36,11 & 30,08 \\
\hline Маса суцвіть на один пагін, г & - & 11,7 & 17,14 & 12,04 & 13,67 \\
\hline Маса одного суцвіття, г & - & 7,71 & 6,05 & 3,91 & 2,89 \\
\hline Діаметр суцвіття, см & - & 3,52 & 3,16 & 2,56 & 2,15 \\
\hline \multicolumn{6}{|c|}{ Суцвімтя разом } \\
\hline Кількість на рослину, шт. & 7,35 & 8,1 & 8,8 & 9,2 & 10,4 \\
\hline Кількість на один пагін, шт. & 1,9 & 3,0 & 3,3 & 3,0 & 4,7 \\
\hline Маса суцвіть однієї рослини, г & 5,33 & 42,35 & 53,14 & 36,11 & 30,08 \\
\hline Маса суцвіть на один пагін, г & 1,41 & 15,7 & 17,14 & 12,04 & 13,67 \\
\hline Маса одного суцвіття, г & 0,73 & 5,23 & 6,05 & 3,91 & 2,89 \\
\hline Діаметр суцвіття, см & 0,98 & 2,20 & 3,16 & 2,56 & 2,15 \\
\hline
\end{tabular}

На пагоні суцвіття починають утворюватися в травні, й перший порядок зацвітає в червні. Згодом можуть розвиватися суцвіття на пагонах другого, третього та інших порядків, кількість яких може бути до 6-8 штук. Відповідно до цього, одна рослина несе суцвіття різних стадій розвитку. В середньому на одній рослині в травні спостерігається 7,4 шт., а червні - 4,0 шт. не роз- 
квітлих суцвіть масою 5,33 г і 10,74 г відповідно. В червні починається квітування, i на одній рослині налічується 4,1 шт. суцвіть масою 31,6 г. У липні кількість усіх суцвіть збільшується до 8,8 шт., серпні - до 9,2 шт., вересні - 10,4 шт. При цьому їх маса, відповідно, становила 53,14 г, 36,11 г та 30,08 г. Цікавий той факт, що в кінці вегетації зменшується маса суцвіть. Це відбувається за рахунок утворення в серпні - вересні суцвіть нижніх порядків, які менші за розміром, а також усихання суцвіть перших порядків, у яких дозріває насіння. На одному пагоні максимальна кількість суцвіть у вересні - 4,7 шт., а найбільша маса - в липні - 53,14 г. Маса одного суцвіття зростає до липня $(6,05$ г), а в наступні місяці знижується до 2,89 г. Аналогічна закономірність має місце й при вимірюванні діаметра суцвіть.

Нам відома обмежена кількість літературних джерел стосовно біологічних особливостей цвітіння ехінацеї блідої [11-13]. У країнах СНД це питання взагалі детально не вивчалося, що й стало підставою для проведення дослідів на модельних рослинах у 2006-2007 pp., де ми систематично проводили спостереження за розвитком суцвіть, фіксуючи їх діаметр, довжину крайових квіток, тривалість цвітіння трубчастих квіток кошиків усіх порядків.

Із наведених на рисунку 4 даних можна зроби- ти висновок, що суцвіття першого порядку має найбільший діаметр (до 37 мм), у інших кошиків діаметр коливався в межах 23-32 мм. Якщо оцінювати темпи приросту, то вони знаходилися на одному рівні незалежно від розташування суцвіть на рослині. Середня швидкість росту суцвіття першого порядку була 0,46 мм/добу, однак в окремі періоди розвитку вона підвищувалась до 11 мм/добу. У той же час, із 40-ої по 50-ту добу діаметр не збільшувався взагалі, до того ж на всіх суцвіттях, що, вірогідно, пов'язано 3 агрометеорологічними факторами. Ростові процеси з високою точністю описуються рівняннями: $\mathrm{Y}=0,4949 \mathrm{X}+13,01\left(\mathrm{R}^{2}=0,94\right) ; \mathrm{Y}=$ $-0,0084 X^{2}+0,9427 X+9,4442\left(R^{2}=0,99\right)$. Не встановлено також корелятивних залежностей між діаметром суцвіть ехінацеї блідої та їх розташуванням на стеблі.

На рисунку 5 наведені результати спостережень за розвитком суцвіть ехінацеї блідої. Суцвіття першого порядку утворюється раніше за всіх, і його темпи розвитку відрізняються від кошиків інших порядків. Після початку розвитку кошика вже через 12-16 діб починається висування крайових квіток, через 32-37 діб - квітування суцвіття, яке триває 15-17 діб (рис. 5). Таким чином, увесь цикл від утворення до кінця цвітіння триває 47-54 діб.

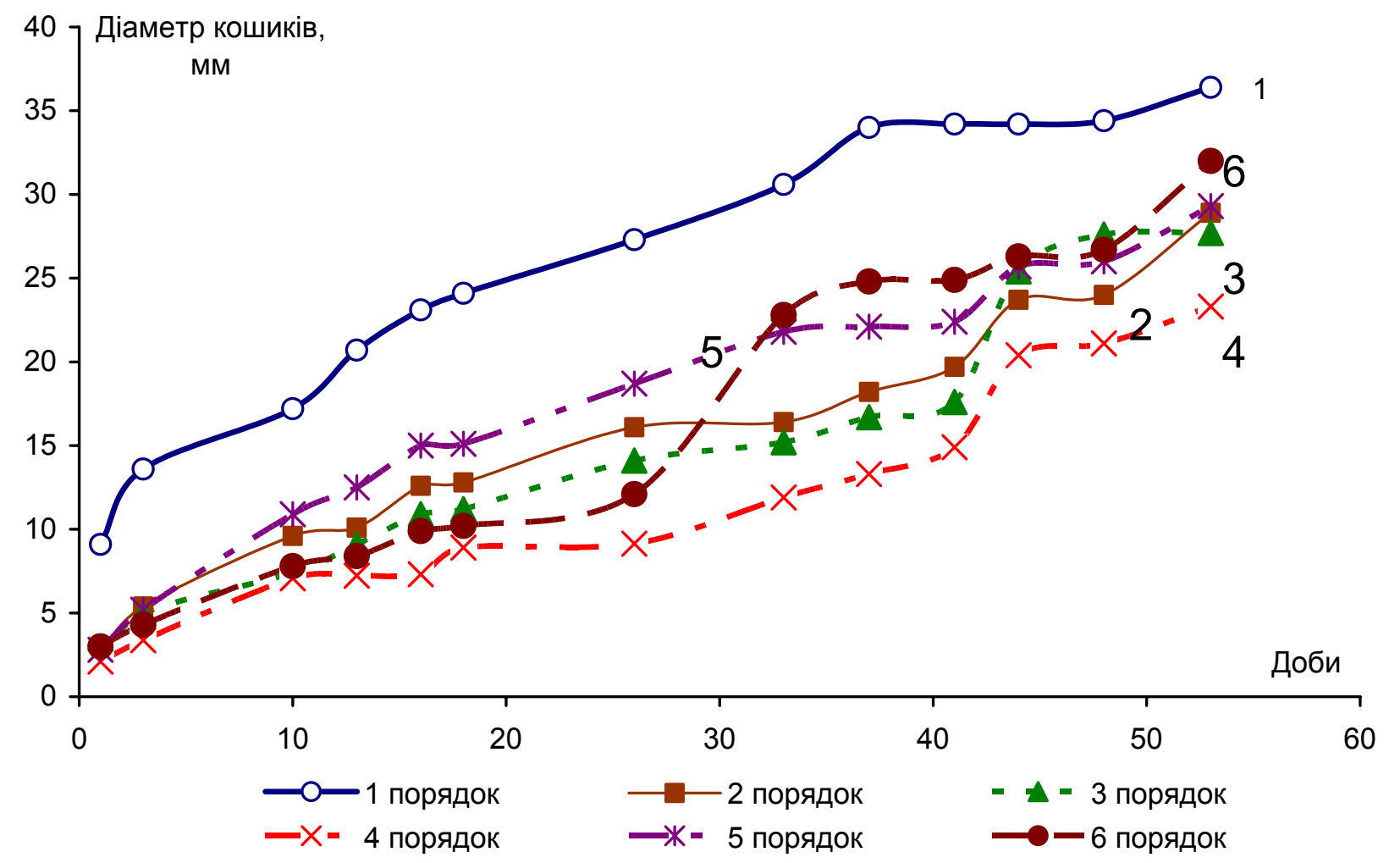

Рис. 4. Динаміка зростання діаметра суцвіть ехінацеї блідої 
Суцвіття інших порядків починають розвиватися на 3-5 діб пізніше за перше й темпи їх розвитку мало відрізняються між собою. Від початку утворення суцвіть до висування пелюсток проходить 25-27 днів. Із цього часу вони починають квітувати через 10-12 діб. Цвітіння триває 20-26 діб залежно від розміру суцвіття та його розташування. Кошики шостого порядку розвивалися найдовше - весь цикл від утворення до цвітіння продовжувався 43-46 діб. Таким чином, увесь цикл рослини від утворення генеративних органів до кінця цвітіння триває 47-56 діб.

Крайові квітки суцвіть ростуть достатньо активно: у суцвіття першого порядку середня швидкість становить 1,7 мм/добу, у кошиків інших порядків - 1,22-1,85 мм/добу. В окремі періоди росту швидкість зростає до 3,8 мм/добу.

Довжина відгину крайових квіток у ехінацеї блідої перевищує діаметр суцвіть (що є видовою особливістю) й відрізняє iі від ехінацеї пурпурової та ехінацеї вузьколистої. Як показано на рисунку 5, їх розмір може сягати 70-ти мм, а максимальні показники характерні для кошиків першого порядку.

Ріст суцвіть і пелюсток крайових квіток із достатньо високою точністю описується поліноміальними рівняннями третього-п'ятого порядків, що представлено на рисунку 5.

Цвітіння ехінацеї блідої в умовах Лісостепу України розпочинається у червні. Подовженість цього процесу має важливе господарське значення й визначає оптимальні строки збирання сировини, використання іiі у медоносному конвеєрі. Слід зауважити, що в країнах СНД особливості біології цвітіння ехінацеї блідої не вивчалися, тому наразі виникла необхідність їх дослідження.

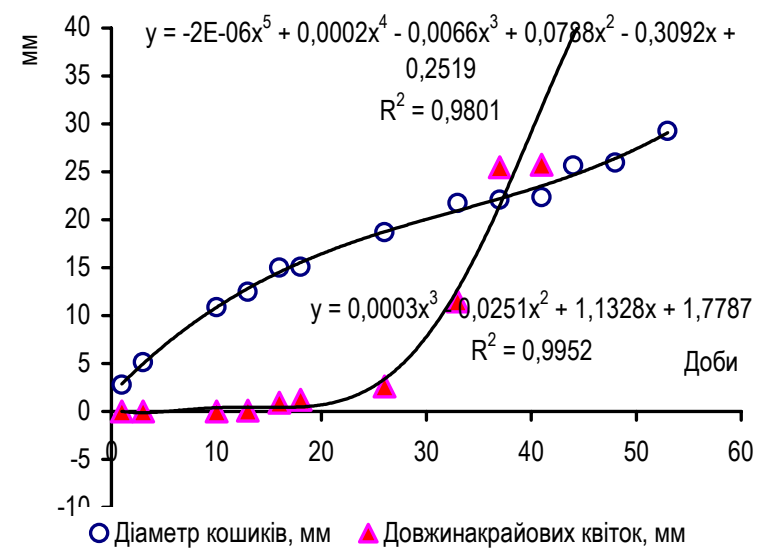

П'ятий порядок

Перший порядок

Рис. 5. Динаміка розвитку суцвіть ехінацеї блідої

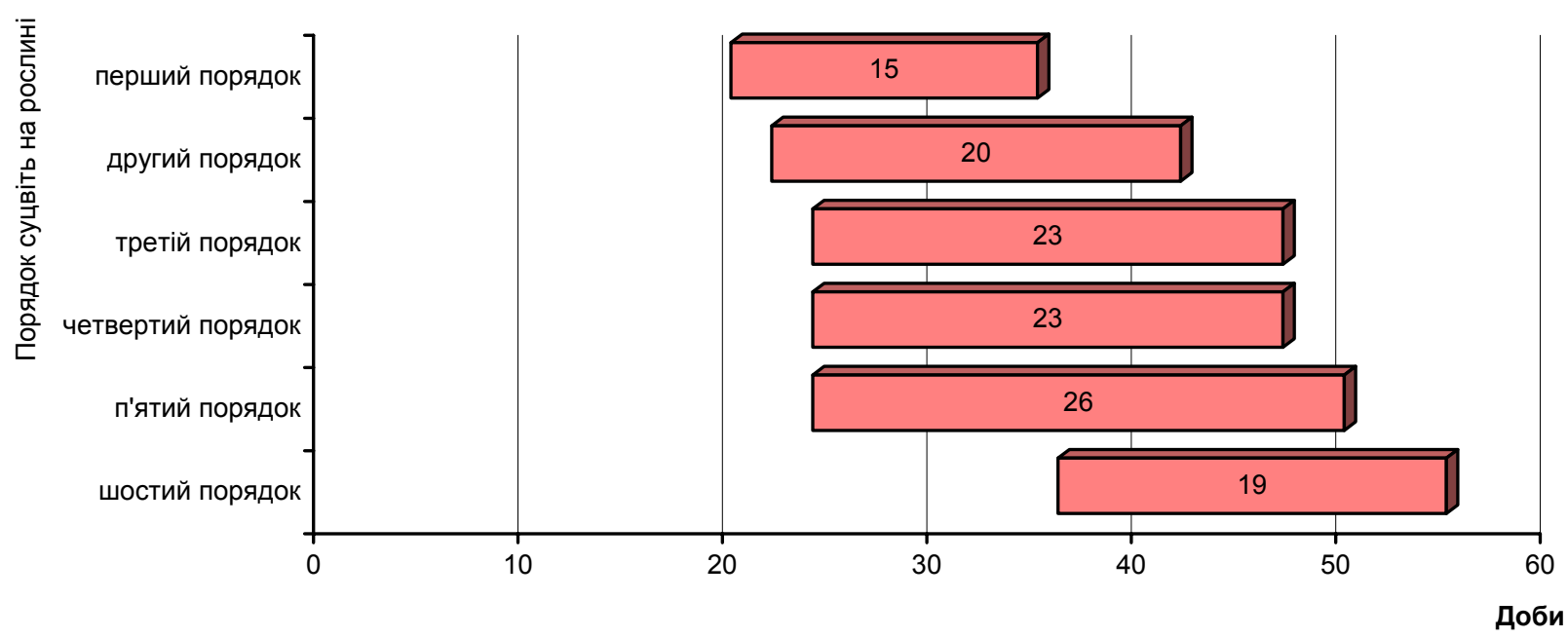

Рис. 6. Тривалість цвітіння суцвіть ехінацеї блідой (від початку висування крайових квіток) (2006-2007 pp.) 


\section{3. Морфометрична характеристика суцвіть і тривалості цвітіння ехінацеї}

\begin{tabular}{|c|c|c|}
\hline Показник & E. purpurea & E. pallida \\
\hline Кількість суцвіть на рослину, шт. & 48,23 & 10,4 \\
Кількість суцвіть на один пагін, шт. & 5,13 & 4,7 \\
Маса суцвіть рослини, г & 184,3 & 30,1 \\
Маса суцвіть пагона, г & 19,6 & 13,7 \\
Маса одного суцвіття, г & 3,8 & 2,9 \\
Діаметр суцвіття першого порядку, мм & 42 & 35 \\
Довжина/ширина відгину крайової квітки суцвіття & $45 / 4,2$ & $71 / 3,2$ \\
першого порядку, мм & & \\
Тривалість цвітіння суцвіть першого порядку, діб & 34 & 15 \\
Тривалість цвітіння рослини, діб & $63-65$ & $34-37$ \\
\hline
\end{tabular}

Суцвіття першого порядку розпочинає цвітіння через 18-20 діб після висування пелюсток крайових квіток і триває в середньому 15 діб. Як видно $з$ даних, наведених на рисунку 6, термін цвітіння першого суцвіття найкоротший. Через 3-6 діб розпочинається цвітіння суцвіть другого порядку, а згодом і 3-5-го порядків. Вони квітують у середньому 20-26 діб.

Останнім зацвітає кошик шостого порядку. Таким чином, загальний період квітування ехінацеї блідої становить у середньому 34-37 діб.

У таблиці 3 наведені дані, за якими можна порівняти два виду ехінацеї за основними параметрами утворення та розвитку суцвіть.

Метричні й вагові показники суцвіть ехінацеї пурпурової, порівняно з ехінацеєю блідою, більші: суцвіть на один пагін (5,13 шт. проти 4,7 шт.), маса одного кошика (3,8 г проти 2,9 г), діаметр суцвіття першого порядку (42 мм проти 35 мм).

За рахунок більш продуктивного утворення генеративних пагонів маса суцвіть однієї рослини ехінацеї пурпурової в 6,1 разу перевищує ехінацею бліду, що суттєво впливає на продуктивність трави та іiі якість.

Характерною особливістю ехінацеї блідої є довжина відгину крайової квітки - 71 мм, проти 45 мм у ехінацеї пурпурової.

Тривалість цвітіння ехінацеї пурпурової майже вдвічі перевищує ехінацею бліду, що важливо й необхідно брати до уваги для створення кормових і медоносних агроценозів.

\section{БІБЛІОГРАФІЯ}

1. Гетко Н. В., Кабушева И. Н., Кручонок А. В. Эхинацея: интродукционное изучение, селекция и культивирование в Беларуси / науч. ред. В. Н. Решетников. - Мн.: Беларус. наука, 2006. $164 \mathrm{c}$.

2. Журавель T. О. Інтродукція видів роду Echinacea Moench на південний схід України. Автореф дис. ... канд. біол. наук (03.00.05 - ботаніка). -
Висновки. Проведені дослідження дали змогу встановити основні закономірності цвітіння двох видів ехінацеї в умовах Лісостепу України:

1. Суцвіття ехінацеї пурпурової починають утворення $з$ травня, масове квітування - 3 липня. Одна рослина за сезон утворює 48,2 шт. кошиків масою 184,25 г. Середня маса одного суцвіття 3,82 г, діаметр - 2,41 см. Від початку утворення кошика першого порядку до початку висування крайових квіток проходить 20-28 діб, через чотири-шість діб починає квітування, що триває в середньому 34 доби. Загальний період квітування рослини триває близько 65 діб.

2. В ехінацеї блідої генеративний період відрізняється від ехінацеї пурпурової. Утворення суцвіть починається також із травня, але масове квітування - вже у червні. Рослина за сезон утворює в середньому 10,4 шт. суцвіть масою 30,1 грам. Маса одного суцвіття становить 2,9 г, діаметр $-2,15$ см. Після початку розвитку кошика першого порядку через 12-16 діб починається висування крайових квіток, далі, через 18-20 діб - квітування, яке триває 15-17 діб. Загальний період цвітіння рослини триває 34-37 діб.

3. Проведені дослідження дають можливість враховувати біологічні особливості при конструюванні лікарських, кормових і медоносних агроценозів ехінацеї, плануванні збирання надземної маси на лікарську сировину, регуляції продуктивності й тривалості цвітіння.

K., 2005. -22 c.

3. Кириова М. В., Конон Н. Т., Коротких И. Н. [u $\partial p$.] Методы оценки селекционных образцов эхинацеи пурпурной // Материалы Международной научн. конф., посвящ. 75-летию Всерос. НИИ лекарственных и ароматических растений: Сб. науч. тр. : Лекарственное растениеводство. M., 2006. - C. 279-284. 
4. Кириова М. В., Коротких И. Н. Селекционная ценность коллекционных образцов эхинацеи // Генетические ресурсы лекарственных и ароматических растений / Сб. науч. тр. Международной конф. - М., ВИЛАР, 2004. - С. 156-159.

5. Меньшова В. А. Использование эхинацеи пурпурной для обогащения медоносных ресурсов Украины // Пчеловодство // Республ. межвед. темат. науч. сб. - К., 1986. - С. 29-31.

6. Порада А. А., Рабинович А. М. Биология цветения эхинацеи пурпурной в условиях Полтавской области // Бюл. ГБС АН СССР. - 1991. № 160. - C. 7-10.

6. Самородов В. Н., Поспелов С. В. Эхинацея в Украине: полувековой опыт интродукции и возделывания. - Полтава: Верстка, 1999. - 52 с.

7. Смык Г. К., Меньшова В. А. Интродукция и первичная культура эхинацеи пурпурной (Echinacea purpurea (L.) Moench) на севере Украины // Охрана, изучение и обогащение растит. мира. - К., 1986. - Вып. 13. - С. 113-116.

8. Соломаха Т. Д. Использование эхинацеи пурпурной в медоносной базе Украины // С эхина- цеей в третье тысячелетие : Материалы Международной научн. конф. / Полтава, 7-11 июля 2003 г. - Полтава, 2003. - С. 96-98.

9. Черкасова А. И., Солошенко Л. Н. Эхинацея пурпурная - перспективный медонос // Изучение и использование эхинацеи / Материалы Международной научн. конф. / Полтава, 21-24 сент. 1998 г. - Полтава: Верстка, 1998. - С. 45-46.

10. Echinacea: the genus Echinacea / ed. by Sandra Carol Miller. - CRC Press. - 2004. - 276 p.

11. Franke R., Schenk R. Echinacea - influence of cultivation method on yield content of active principles // Echinacea Symposium. - June 3-5, 1999. - Ritz-Carlton. - Kansas City, Mo (USA).

12. Muntean L., Tamas M. Specii de Echinacea de perspectiva in Romania // Herba rom. - 1989, \#9 P. 79-85.

13. Tyler J. Wist Pollination biology of Echinacea angustifolia and Echinacea purpurea (Asteracea) in Saskatchewan / A thesis ... degree of Master of Science in the Department of Biology University of Saskatchewan. - Saskatoon, Saskatchewan, Canada. -2005 . $-178 \mathrm{p}$. 